\title{
The Potentials of Iron and Steel Slags as Supplementary Cementitious Materials in the Nigerian Construction Industry: A Review
}

\author{
Ogirigbo, O.R. ${ }^{1{ }^{*}}$, Ukpata, J.O. ${ }^{2}$ and Inerhunwa, I. ${ }^{1}$ \\ ${ }^{1}$ Department of Civil Engineering, Faculty of Engineering, University of Benin, Benin City, Edo State, Nigeria \\ ${ }^{2}$ Department of Civil Engineering, Faculty of Engineering, Cross River University of Technology, Calabar, \\ Cross River State, Nigeria
}

Corresponding Author: *okiemute.ogirigbo@uniben.edu

\begin{abstract}
Ground Granulated Blast Furnace Slag (GGBS) is a type of Supplementary Cementitious Material $(S C M)$ that is currently being used extensively in the global construction industry. SCMs are cheaper than Portland cement, help to improve certain properties of concrete and also help to reduce the environmental footprint associated with the production of Portland cement. GGBS is readily available in most parts of the world as a waste product from iron and steel production. However, its use as a SCM in some countries has not been fully maximized. This is primarily because of lack of documented studies on the properties of GGBS that influences its suitability as a $S C M$, especially in tropical environments. This paper reviewed the use of GGBS as a SCM for the partial replacement of Portland cement, with particular emphasis on its potential use in tropical warm environments such as Nigeria and other similar countries.
\end{abstract}

Keywords: GGBS, Tropical environment, SCM, Slag hydraulicity, Slag blends

\subsection{Introduction}

Slag is the by-product obtained from the production of iron and steel. In the production of iron, the iron oxide ore is reduced to metallic iron by means of a flux (limestone or dolomite) at temperatures of about 1400 to $1500^{\circ} \mathrm{C}$. During the heating process, the impurities in the iron ore comprising mainly of silica and alumina, combine with lime and magnesia to form a molten slag which is collected separately from the molten iron via the bottom of the blast furnace (Siddique and Bennacer, 2012).

Currently, there is no reliable data regarding the global production of slag. However, in a report by Van Oss (2016), the global iron slag output in 2015 was estimated to be in the range of 300 to 360 million metric tons, while that of steel slag was about 170 to 250 million tons. These figures were obtained based on typical ratios of slag to crude iron and steel output. According to Van Oss (2002), a steel furnace will generate about 0.2 metric ton of steel slag per ton of crude steel. However, about half of this steel slag will be comprised of entrained metal, which is usually removed and put back in the steel furnace, thus reducing the amount of steel slag produced to about 0.1 metric ton per ton of crude steel.

Ohimain (2013) reported that the Nigerian steel sector was being upheld by the recycling of scrap steel obtained from municipal solid wastes and that this resulted in the production of $7-15 \%$ slag for low and high carbon steel respectively. In another report by Akinwumi (2012), it was estimated that about 3.5 to 4.5 million metric tonnes of steel was being produced per annum by the steel plants in Ajaokuta, Delta, Jos, Katsina and Osogbo. This implies that approximately 0.35 to 0.45 million metric tons of steel slag is produced per annum in Nigeria.

Currently, the rate of utilization of slags in Nigeria is very low and as a result, there is increase in the volume of slag piles at dump sites and landfills (Ohimain, 2013). Despite the numerous range of 
applications for which slags can be used, only very few studies have reported the use of slags in Nigeria and in most of these studies slag was not used as a partial replacement material for Portland cement, but as a stabilization agent for problematic soils as seen in the study by Akinwumi (2012). Similar low utilization had been reported in the past on a global scale, as shown in Figure 1. However, some developed countries seem to be experiencing shortage of slag supply, given recent evidence in the literature (Miller, 2018). Akinwumi (2012) observed that steel slag can be utilized in the stabilization of lateritic soils at proportions up to $8 \%$, while Olonade et al. (2015) reported that up to $50 \%$ replacement of fine aggregates by steel slag resulted in an increase in the compressive strength of concrete. This is below the range of GGBS replacement levels reported by (Oner and Akyuz, 2007) for achieving optimal compressive strengths.

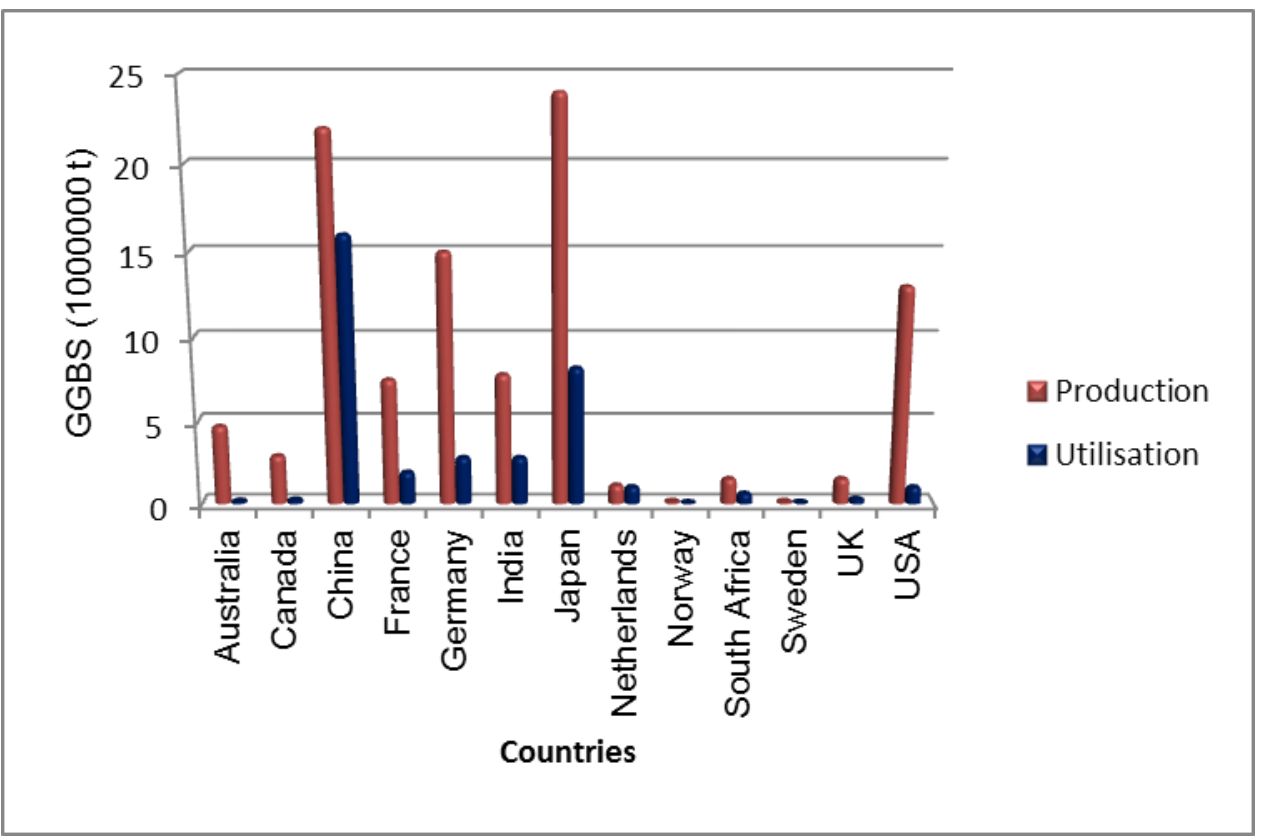

Figure 1: Production and utilization of GGBS by different countries [Adapted from (MoranvilleRegourd, 2003)]

Slags ground to finer particle sizes, otherwise known as Ground Granulated Blast Furnace Slag (GGBS), has been shown to possess cementitious properties and can be used as a Supplementary Cementitious Material (SCM) in combination with Portland cement (PC) at various proportions ranging from as low as 6\% to as high as 95\% (EN197-1: 2011). GGBS is latently hydraulic (Shi et al., 2012) and reacts with water at a much slower rate as compared to PC (ACI-233R-03: 2003). Amongst the common SCMs, only GGBS has the hydraulic cementing nature similar to Portland cement (Hossain, 2006). The ease with which GGBS reacts with water, otherwise known as hydraulicity, has been found to be dependent on various factors. This paper takes a critical look at some of these factors and how they influence the performance of slag blended cements, relating it to suitability of application in tropical environments like Nigeria.

\subsection{Properties of GGBS that influences its performance as a SCM}

\subsection{Physical properties of $G G B S$}

\subsubsection{Particle fineness}

The fineness of GGBS is a very important parameter that influences its hydraulicity, and often times, recommendations are given in Standards as to what should be the minimum value. For example, EN15167-1: 2006 recommends that the specific surface area of GGBS should not be less than 275 $\mathrm{m}^{2} / \mathrm{kg}$. According to Swamy (1998), an increase in fineness of GGBS to two or three times that of PC, will lead to enormous improvement in a variety of engineering properties such as bleeding, setting time, heat evolution, strength and durability. In the study by Gao et al. (2005), the hydration characteristics of two slag blends with the same chemical composition but different degrees of fineness, were investigated using XRD and SEM. The slags had specific surface areas of 425 and 600 
$\mathrm{m}^{2} / \mathrm{kg}$ respectively and were used to replace PC at $40 \%$. They observed a higher degree of slag hydration for the finer slag, and concluded that slag hydration was a function of the specific surface area of the slag.

Moranville-Regourd (2003) reported that for PC - slag blends containing between $50-60 \%$ of slag, the early strength was influenced mainly by the clinker fineness and the later age strength by the slag fineness; whereas for blends containing higher slag proportion, the fineness of the slag had major influence on strength at all ages. Table 1 shows a typical example of how concrete's strength can be influenced by slag's fineness for a 30:70 PC:GGBS blend. From the table, it can be clearly seen that the higher the specific surface area of the slag, the more reactive it will be.

Table 1: Influence of slag fineness on strength of concrete (Moranville-Regourd, 2003)

\begin{tabular}{|l|l|l|l|l|l|}
\hline \multirow{2}{*}{$\begin{array}{c}\text { Blaine fineness } \\
\left(\mathrm{cm}^{2} / \mathrm{g}\right)\end{array}$} & \multicolumn{5}{l}{ Compressive strength $(\mathrm{MPa})$} \\
\cline { 2 - 6 } & 1 day & 3 days & 7 days & 28 days & 90 days \\
\hline 3095 & 0.72 & 2.48 & 5.90 & 16.96 & 27.23 \\
\hline 3930 & 0.88 & 2.88 & 8.41 & 21.79 & 32.34 \\
\hline 4850 & 1.05 & 3.60 & 10.58 & 24.82 & 36.34 \\
\hline 6140 & 1.19 & 4.87 & 12.48 & 27.06 & 39.09 \\
\hline
\end{tabular}

PC:GGBS $=30: 70$, Gravel concrete $(1: 2: 4$ by vol $), w / b=0.55$, water cured

\subsubsection{Particle size distribution}

Properties such as fluidity and compressive strength can be influenced by the particle size distribution of GGBS. In a study by Wan et al. (2004), a particular type of GGBS was ground to the same degree of fineness using three different techniques - ball mill (with steel balls as the grinding medium), laboratory vibromill, and an industrial airflow mill. They observed that the samples ground by the ball mill had the widest particle size distribution, followed by those ground by the laboratory vibromill. Fluidity was greater for samples having narrow particle size distribution. In terms of strength properties, mixes made from GGBS samples containing more particles of size $<3$ microns, had higher early strengths; while those containing more particles in the size range of 3 to 20 microns had higher later strengths.

\subsubsection{Glass content}

The glass content of GGBS also has considerable effect on its reactivity, and it is influenced by the rate of quenching of the molten slag. Slags that are cooled rapidly will contain a high amorphous glassy phase and low crystalline phases. The glass fraction is generally considered to be very reactive while the crystalline part is considered to be inert (Mehta, 1989). In a typical XRD pattern of a slag, the glassy part of the slag will appear as a large hump peaking at $d$-values of about $0.3 \mathrm{~nm}$ (or $2 \theta$ values of about $30^{\circ}$ as shown in Figure 2); while the crystalline fraction comprising mainly of melilite, merwinite, calcite and quartz, will appear as little peaks around the large hump (Smolczyk, 1980; Regourd, 1986). Typical glass content of GGBS vary between 85 and 99\% (Siddique and Bennacer, 2012). EN197-1: 2011 specifies that at least two-third of the mass of the slag must be glassy, although research data show that slag samples with as little as $30-65 \%$ glass contents are still suitable (Pal et al., 2003).

The structure of the amorphous glass phase comprise mainly of isolated or polymerized silica tetrahedral with bridging oxygen atoms. These silicates are mostly present as monomers and dimers (Mehta, 1989). Cations such as $\mathrm{Ca}^{2+}$ or $\mathrm{Mg}^{2+}$, referred to as network modifiers, are often coordinated in the cavities of the network to neutralize the negative charges resulting from the Si-O-Si covalent bonds. The coordination of calcium atoms are considered as octahedral while that of magnesium atoms as either octahedral or both octahedral and tetrahedral (Regourd, 1986). Aluminium can also be coordinated as a network modifier, in the forms of $\mathrm{Al}^{3+}, \mathrm{AlO}^{+}$or $\mathrm{AlO}_{4}^{5-}$ (Smolczyk, 1980; Regourd, 1986). The tetrahedral atoms are the network formers while the octahedral atoms are the network modifiers (Satarin, 1974). Higher number of network modifiers present in the structure will result in a smaller polymerization degree, and higher reactivity of the slag (Smolczyk, 1980). 


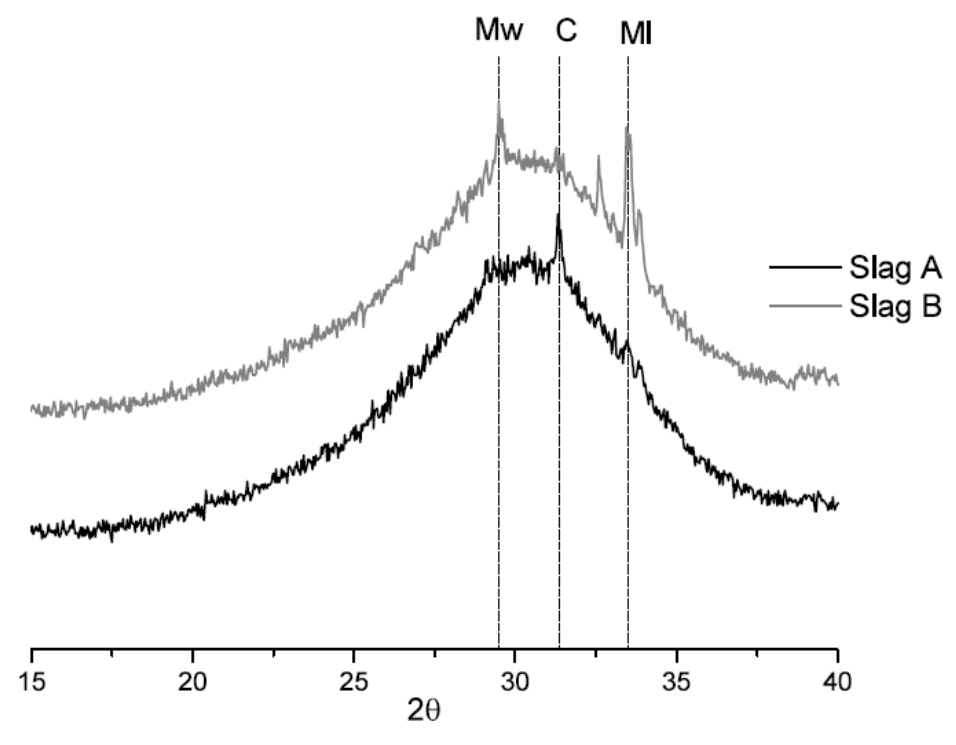

C - Calcite, Ml - Melilite, Mw - Merwinite

Figure 2: XRD patterns of two slags showing the crystalline phases (Ogirigbo and Black, 2016)

\subsection{Chemical properties of GGBS}

The chemical composition of slag can vary over a wide range depending on the nature of the ore, the composition of the limestone flux, coke consumption and the type of iron being made. It can also change over the years with alterations in the sources and types of ore being smelted. In general, the lime content may be in the range $30-50 \%$, silica $28-38 \%$, alumina $8-24 \%$, magnesia $1-18 \%$, sulphur $1-2.5 \%$ and ferrous and manganese oxides $1-3 \%$. Other minor components are $\mathrm{TiO}_{2}$, which is usually less than $4 \%$, and $\mathrm{Na}_{2} \mathrm{O}+\mathrm{K}_{2} \mathrm{O}$, which is less than $2 \%$ (Moranville-Regourd, 2003).

The oxides of calcium, magnesium and aluminium are known to increase the hydraulicity of GGBS, while those of silicon and manganese decrease it (Haha et al., 2012). Ratios of some of these oxides have been used by various standards to assess the hydraulicity of a slag. For example, EN197-1: 2011 prescribes that for GGBS, the $(\mathrm{CaO}+\mathrm{MgO}) / \mathrm{SiO}_{2}$ ratio by mass must exceed 1. Several workers (Smolczyk, 1979; Pal et al., 2003), have also suggested other oxide ratios, some of which are shown in Table 2. However, some studies (Mantel, 1994; Bougara et al., 2010) have shown that these ratios do not necessarily give accurate prediction of a slag's performance.

Table 2: Formulas proposed for assessment of hydraulicity of GGBS (Ogirigbo, 2016)

\begin{tabular}{|l|l|l|l|}
\hline & Basicity/hydraulic index & $\begin{array}{l}\text { Requirement for good } \\
\text { performance }\end{array}$ & Remarks \\
\hline P1 & $\mathrm{CaO} / \mathrm{SiO}_{2}$ & $1.3-1.4$ & $\begin{array}{l}\text { Mantel (1994) proposed for } \\
\text { medium-fine slags of } 350 \mathrm{~kg} / \mathrm{m}^{2}, \mathrm{P} 1 \\
\text { or P2 must be greater than } 1.0\end{array}$ \\
\hline P2 & $(\mathrm{CaO}+\mathrm{MgO}) / \mathrm{SiO}_{2}$ & $\begin{array}{l}\text { Here } \mathrm{Al}_{2} \mathrm{O}_{3} \text { is assumed to have a } \\
\text { negative influence }\end{array}$ \\
\hline P3 & $(\mathrm{CaO}+\mathrm{MgO}) /\left(\mathrm{SiO}_{2}+\mathrm{Al}_{2} \mathrm{O}_{3}\right)$ & $1.0-1.3$ & $\begin{array}{l}\text { In Japan, must be } \geq 1.4 \\
\text { (Moranville-Regourd, 2003); while } \\
\text { in S. Korea, must be } \geq 1.6 \text { (Jeong } \text { et } \\
\text { al., 2016) }\end{array}$ \\
\hline P4 & $\left(\mathrm{CaO}+\mathrm{MgO}+\mathrm{Al}_{2} \mathrm{O}_{3}\right) / \mathrm{SiO}_{2}$ & $\geq 1.0$ & \\
\hline P5 & $\begin{array}{l}\mathrm{CaO}+0.56 \mathrm{Al}_{2} \mathrm{O}_{3}+ \\
1.4 \mathrm{MgO} / \mathrm{SiO}_{2}\end{array}$ & $\geq 1.65$ & \\
\hline P6 & $\mathrm{Al}_{2} \mathrm{O}_{3} / \mathrm{SiO}_{2}$ & $0.53-0.55$ & \\
\hline
\end{tabular}

$\mathrm{MgO}$ has the same influence as $\mathrm{CaO}$ up to about $11 \%$ by weight (Moranville-Regourd, 2003). The influence of $\mathrm{P}_{2} \mathrm{O}_{5}$ depends on the clinker type and test age, but generally has a positive influence beyond 28 days of curing. Oxides of tin and iron, as well as sulphur, seem not to have any effect.

Increasing the $\mathrm{Al}_{2} \mathrm{O}_{3}$ content to $13 \%$ and above will result in an increase in early strength and a decrease in the later strength (Satarin, 1974). Wang et al. (2004) observed a positive correlation between the $\mathrm{Al}_{2} \mathrm{O}_{3}$ content and the reactivity of the slags, for slags having a $\mathrm{CaO}$ content greater than $37 \%$. In the studies by (Haha et al., 2011, 2012), it was observed that the reactivity of the slags increased with the magnesia content. As they increased the alumina content, the reactivity of the slags were reduced at early ages, but became similar at later ages beyond 28 days. Perhaps, the reason for 
the reduced reactivity observed in the study by (Haha et al., 2012), may be due to the $\mathrm{CaO}$ content of the high alumina slags, which in their case was less than $37 \%$.

Several studies (Dhir et al., 1996; Luo et al., 2003; Cheng et al., 2005; Thomas et al., 2012) have also reported that the alumina content of GGBS contributes significantly to chloride binding, due to the increased possibility of forming Friedel's salt and also the formation of C-A-S-H phases that is responsible for the binding of about two-thirds of the chloride (Florea and Brouwers, 2012). This is the main reason why slag blends are more resistant to the ingress of chloride ions than plain cements, as has been reported in various studies (Ramezanianpour and Malhotra, 1995; Sengul and Tasdemir, 2009; Shi et al., 2011; Bouteiller et al., 2012).

\subsection{Other properties that influence the reactivity of $G G B S$}

\subsubsection{Type of activator used}

Slag activators can either be alkaline in nature, such as sodium hydroxide, lime, sodium carbonate and sodium silicate; or sulphate-based, like calcium sulphates or phosphogypsum. The type of the activator influences the nature and type of the hydrates formed (Moranville-Regourd, 2003; Siddique and Bennacer, 2012). Table 3 gives a summary of the hydration products obtained when different activators were used.

Table 3: Slag hydration products in the presence of different activators (Glasser, 1991)

\begin{tabular}{|l|l|l|}
\hline Nature of activator & Crystalline phases & Comments \\
\hline $\mathrm{NaOH}, \mathrm{Na}_{2} \mathrm{CO}_{3}$, sodium silicate & $\begin{array}{l}\mathrm{C}-\mathrm{S}-\mathrm{H}, \mathrm{C}_{4} \mathrm{AH}_{13}, \mathrm{C}_{2} \mathrm{AH}_{8}, \\
\mathrm{Mg}(\mathrm{OH})_{2}\end{array}$ & $\begin{array}{l}\text { Some } \mathrm{Si} \text { in } \mathrm{C}_{3} \mathrm{AH}_{13}, \mathrm{C} / \mathrm{S} \text { in C-S-H less } \\
\text { than in OPC }\end{array}$ \\
\hline $\mathrm{Ca}(\mathrm{OH})_{2}$ & $\mathrm{C}-\mathrm{S}-\mathrm{H}, \mathrm{C}_{4} \mathrm{AH}_{13}$ & $\mathrm{C}_{2} \mathrm{AH}_{8}$ absent \\
\hline $\begin{array}{l}\text { Sulphate e.g. gypsum, hemihydrates, } \\
\text { phosphogypsum }\end{array}$ & $\mathrm{C}-\mathrm{S}-\mathrm{H}, \mathrm{AFt}, \mathrm{Al}(\mathrm{OH})_{3}$ & $\begin{array}{l}\text { Sulphate in slag acts to some extent as } \\
\text { an auto-activator }\end{array}$ \\
\hline Portland cement & $\begin{array}{l}\text { C-S-H, AFm, AFt, } \\
\text { hydrogarnet, hydrotalcite- } \\
\text { like phase }\end{array}$ & $\begin{array}{l}\text { Not all phases are likely to be seen in } \\
\text { the same paste }\end{array}$ \\
\hline
\end{tabular}

In the study by Ben Haha et al. (2011), slags were activated by two different alkalis - $\mathrm{NaOH}$ and waterglass (sodium silicate). They observed that the $\mathrm{NaOH}$ activated slags were more reactive than the waterglass activated slags at the early stages. However, at ages beyond 7 days the trend was reversed. In terms of the impact on the microstructure, the initial fast reaction of the $\mathrm{NaOH}$ activated slags resulted in a more porous microstructure; whereas the slow hydration of the waterglass activated slag led to a more refined microstructure. Similar findings were reported by Jeong et al. (2016), where they investigated the influence of four supplementary activators on $\mathrm{Ca}(\mathrm{OH})_{2}$ activated slag system. They observed that the Na-based additives were less desirable, producing lower 28 day strengths.

In PC slag blends, the hydration of slag in the presence of the cement depends on the breakdown and dissolution of the glass slag structure by hydroxyl ions released during the hydration of the PC and also on the alkali content of the PC (Güneyesi and Gesoğlu, 2008). The later (alkali content of the PC) cannot be said to be very important as there are no specifications on the minimum alkali content a Portland cement should have before it can be blended with a slag. Also, in contrast to alkali activated systems, using different types of PC as activator for slags does not seem to have any significant effect on the hydration of the slags (Lumley et al., 1996; Scrivener and Nonat, 2011).

\subsubsection{Proportion of slag used}

Whittaker et al. (2014) studied the hydration kinetics of PC slag blends. The two slags they studied had the same fineness but different chemical composition and glass content. They observed that after 1 year of hydration of $60-40$ PC slag blends, about $57 \%$ and $68 \%$ of the slags had reacted. The more reactive slag had higher alumina and glass contents. When they increased the slag loading from 40 to $70 \%$, the degree of slag hydration dropped from $68 \%$ to $60 \%$. In another study, (Luke and Glasser, 1988) observed that for 70-30 PC slag blends, about $41 \%$ and $65 \%$ of the slag had reacted after 1 month and 1 year of hydration respectively. This generally implies that the higher the slag proportion in a mix, the lower the degree of slag hydration (Escalante et al., 2001). Studies have shown that for maximum strength, the optimum amount of slag replacement in PC ranges between 55\% and 59\% 
(Oner and Akyuz, 2007), while up to 65\% has been reported for improved chloride resistance (Arya and $\mathrm{Xu}, 1995)$.

On the other hand, at a given water/binder ratio, increasing the slag proportion will result in a decrease in the chloride diffusion coefficient of concretes prepared from slag blends (Yeau and Kim, 2005; Olsson et al., 2013). Yeau and Kim (2005) conducted rapid chloride permeability tests (RCPT) and accelerated chloride ion diffusion tests on concrete samples made from GGBS and plain cements. They used concrete mixes containing $0,25,40$ and 55\% of GGBS by weight of PC at a constant w/b ratio of 0.42 . Irrespective of the curing duration before exposure, they observed that the chloride penetrability decreased as the proportion of the slag in the concrete mixes was increased, with the 55\% GGBS having the lowest chloride penetrability.

\subsubsection{Curing conditions}

\section{Curing medium:}

In the study by (Ramezanianpour and Malhotra, 1995), slag concrete specimens prepared with a w/b ratio of 0.5 were subjected to four different curing regimes - continuous moist curing, 2 days moist curing followed by air curing, continuous air curing and curing at $38^{\circ} \mathrm{C}$ and $65 \% \mathrm{RH}$. The samples were cured for various lengths of 7, 28 and 180 days before testing for chloride diffusion using RCPT. They observed that the slag concretes were more sensitive to poor curing than the plain concretes, with this effect increasing with greater slag replacements.

\section{Length of curing:}

Yeau and Kim (2005) observed that, for slag concretes, the chloride penetrability decreased as the initial curing before exposure to chloride solution was increased from 28 to 56 days. This was attributed to the effect of prolonged curing on the microstructure, which resulted in a more refined pore structure that had better resistance to the ingress of chloride ions. Similar observation was also reported by (Ogirigbo and Black, 2018), although in their case, they observed that the effect of prolonged curing was more pronounced on slags of lower reactivity. Recent study on the expansion of 30 wt.\% slag-blended mortars exposed to combined sodium chloride and sulphate solution at $20^{\circ} \mathrm{C}$ have shown significant effect of slag reactivity and alumina content on curing duration. Expansion was found to be lower in slag blended mortar bars cured for only 7 days before exposure compared with those cured for 28 days. This was associated with advanced slag hydration leading to more formation of monosulfoaluminate which formed ettringite crystals on reacting with in-coming sulphate ions (Ukpata et al., 2018).

\section{Curing temperature:}

Several studies (Richardson et al., 1989; Ma et al., 1994; Escalante-Garcia and Sharp, 2000) have shown that GGBS contributes more to the total heat of hydration at higher temperatures than at lower temperatures. This has been largely attributed to the accelerating effect of temperature on slag hydration and has been cited as the main reason for the increase in early strength observed for slag blends cured at elevated temperatures (Hogan and Meusel, 1981; Barnett et al., 2006; Çakır and Aköz, 2008). For example, Richardson et al. (1989) hydrated slag blends at elevated temperatures, and observed that the reactions of the silicates and aluminates were accelerated at elevated temperatures. Slags are richer in silica and alumina than PC. Hence, the accelerating effect of temperature on hydration would be more pronounced on slags than plain cements. Ogirigbo and Black (2016), in their study on the combined influence of slag composition and temperature on the hydration of slag blends, observed that the chemical composition of the slags also played an important role. In their study, two slag blends prepared from two slags of different chemical compositions, at a replacement of $30 \%$, were hydrated at temperatures of 20 and $38^{\circ} \mathrm{C}$. The slags had alumina contents of $12.23 \%$ and $7.77 \%$ respectively. They observed that the higher alumina slag (slag 1 as seen in Figure 3) reacted more at both temperatures, and that the difference between the degrees of hydration of the slags was much greater at the higher temperature of $38^{\circ} \mathrm{C}$. They attributed the increased reactivity of the slag 1 blend at the higher temperature to its higher alumina content. 

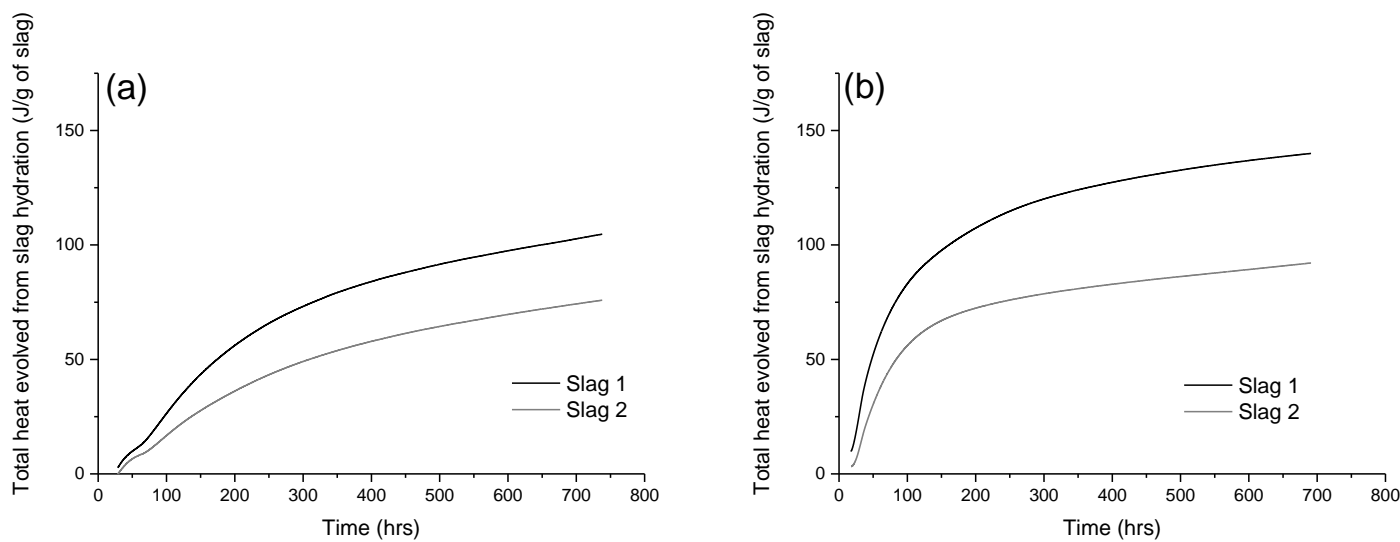

Figure 3: Total heat evolved from slag hydration normalised to the slag content at (a) $20^{\circ} \mathrm{C}$ and (b) $38^{\circ} \mathrm{C}$ (Ogirigbo and Black, 2016)

Some studies (e.g. (Angulski da Luz and Hooton, 2015)) have also shown that curing slag blends at elevated temperatures can result in lower porosity at early ages. Angulski da Luz and Hooton (2015) observed that paste samples made from super sulphated cements and cured for 7 days at higher temperatures had lower porosities than the ones cured at lower temperatures. Similar findings were also reported in the study by (Ogirigbo and Black, 2016). They observed that the porosity of 7 day old paste samples prepared from slag blends were lower for samples cured at $38^{\circ} \mathrm{C}$ as compared to those cured at $20^{\circ} \mathrm{C}$. However, when they increased the curing age from 7 days to 28 days (as shown in Table 4), the trend reversed. They attributed the lower porosity of the 7 day samples cured at $38^{\circ} \mathrm{C}$ to the increased reactivity of the slags at $38^{\circ} \mathrm{C}$, and the higher porosity of the 28 day samples cured at $38^{\circ} \mathrm{C}$ to the coarsening effect of high temperature curing on the microstructure. This seems to suggest that the impact of the accelerating effect of temperature on the hydration of the slags is more pronounced at early ages than at later ages. However, more studies would have to be carried out in this area to fully understand the interplay between curing temperature and slag hydration.

Table 4: Degree of porosity (\%) of PC:slag blends (70:30) at 7 and 28 days measured by SEM image analysis (Ogirigbo and Black, 2016)

\begin{tabular}{|l|l|l|l|l|l|}
\hline Mix & Temperature & 7 days & Error & 28 days & Error \\
\hline \multirow{3}{*}{ Slag 1} & $20^{\circ} \mathrm{C}$ & 11.75 & 0.10 & 6.54 & 0.11 \\
\cline { 2 - 6 } & $38^{\circ} \mathrm{C}$ & 9.21 & 0.14 & 8.87 & 0.08 \\
\hline \multirow{2}{*}{ Slag 2} & $20^{\circ} \mathrm{C}$ & 12.27 & 0.12 & 7.03 & 0.07 \\
\cline { 2 - 6 } & $38^{\circ} \mathrm{C}$ & 9.88 & 0.11 & 9.48 & 0.09 \\
\hline
\end{tabular}

\subsection{Factors to consider for effective utilization of slag in Nigeria}

A number of factors affecting the reactivity of slags have been reviewed to encourage proper and increased use of slags to reduce environmental footprints of concretes. The factors ranged from physical to chemical properties, as well as, the influence of exposure environments - curing conditions and temperature. In summary, the following points are highlighted:

- Slags having fineness greater than $275 \mathrm{~m}^{2} / \mathrm{kg}$ and glass contents within the range of $85 \%$ and 99\% are adequate for use as a supplementary cementitious material.

- The chemical composition of slag depends mainly on the nature of the ore, the composition of the limestone flux, coke consumption and the type of iron being made.

- The main compounds that influence the hydraulicity of slags are the oxides of calcium, magnesium, aluminium and silicon. The first three oxides increase the hydraulicity of slag, while that of silicon decreases it.

- Slags can be activated by alkaline compounds such as sodium hydroxide, lime, sodium carbonate and sodium silicate; or sulphate-based, like calcium sulphates or phosphogypsum; or the hydration products of Portland cement.

- Slags can be used to replace Portland cement in proportions ranging from $6-99 \%$. The higher the proportion of slag, the lower the chloride penetrability and degree of hydration of the slag, and vice versa. 
- Concretes made from cements containing slags are more sensitive to poor curing techniques than those made from plain cements, and they often require longer curing durations for adequate performance.

Higher curing temperatures, typically in the range experienced in Nigeria, enhance the early age performance of cements containing slag due to the accelerating effect of temperature on the reaction of the aluminates and silicates.

\subsection{Conclusion}

A number of countries such as Nigeria are yet to fully utilize their potentials of slags to reduce the cost of concrete binders, as well as reduce the carbon footprints of concrete materials, despite their natural advantage in climates that support improved slag performance. While this review has shown that there is huge potential for incorporating slags into concrete binders in Nigeria, further studies would still need to be carried out to characterize the range of chemical compositions of the slags; as chemical composition is an essential factor influencing the hydraulicity and/or performance of slags, especially in high temperature environments. Except this characterization is carried out, the potential application of GGBS and other types of slags from the abundant steel and iron ore deposits in Nigeria might not be fully realized.

\section{Acknowledgement}

The authors would like to acknowledge the input of Prof. Leon Black of the Center for Infrastructure Materials, School of Civil Engineering, University of Leeds, for his support and contributions towards this work.

\section{References}

ACI-233R-03 (2003) 'Slag Cement in Concrete and Mortar '. Farmington Hills, MI: American Concrete Institute, p. 18.

Akinwumi, I. I. (2012) Utilization of steel slag for stabilization of a lateritic soil. Covenant University, Ota, Ogun State, Nigeria.

Angulski da Luz, C. and Hooton, R. D. (2015) 'Influence of curing temperature on the process of hydration of supersulfated cements at early age', Cement and Concrete Research, 77, pp. 69-75.

Arya, C. and Xu, Y. (1995) 'Effect of cement type on chloride binding and corrosion of steel in concrete', Cement and Concrete Research, 25(4), pp. 893-902.

Barnett, S. J. et al. (2006) 'Strength development of mortars containing ground granulated blastfurnace slag: Effect of curing temperature and determination of apparent activation energies', Cement and Concrete Research, 36(3), pp. 434-440.

Bougara, A., Lynsdale, C. and Milestone, N. B. (2010) 'Reactivity and performance of blastfurnace slags of differing origin', Cement and Concrete Composites, 32(4), pp. 319-324.

Bouteiller, V. et al. (2012) 'Corrosion initiation of reinforced concretes based on Portland or GGBS cements: Chloride contents and electrochemical characterizations versus time', Cement and Concrete Research, 42(11), pp. 1456-1467.

Çakır, Ö. and Aköz, F. (2008) 'Effect of curing conditions on the mortars with and without GGBFS', Construction and Building Materials, 22(3), pp. 308-314.

Cheng, A. et al. (2005) 'Influence of GGBS on durability and corrosion behavior of reinforced concrete', Materials Chemistry and Physics, 93(2-3), pp. 404-411.

Dhir, R. K., El-Mohr, M. A. K. and Dyer, T. D. (1996) 'Chloride binding in GGBS concrete', Cement and Concrete Research, 26(12), pp. 1767-1773. 
EN15167-1 (2006) Definitions, specifications and conformity criteria, Ground granulated blast furnace slag for use in concrete, mortar and grout. Brussels: BSI.

EN197-1 (2011) 'Composition, specifications and conformity criteria for common cements'. Brussels: BSI, p. 1.

Escalante-Garcia, J. I. and Sharp, J. H. (2000) 'The effect of temperature on the early hydration of Portland cement and blended cements', Advances in Cement Research, 12(3), pp. 121-130.

Escalante, J. I. et al. (2001) 'Reactivity of blast-furnace slag in Portland cement blends hydrated under different conditions', Cement and Concrete Research, 31(10), pp. 1403-1409.

Florea, M. V. A. and Brouwers, H. J. H. (2012) 'Chloride binding related to hydration products Part I: Ordinary Portland Cement', Cement and Concrete Research, 42(2), pp. 282-290.

Gao, J. M. et al. (2005) 'ITZ microstructure of concrete containing GGBS', Cement and Concrete Research, 35(7), pp. 1299-1304.

Glasser, F. P. (1991) 'Chemical, mineralogical, and microstructural changes occurring in hydrated slag-cement blends', Materials Science of Concrete II, pp. 41-81.

Güneyesi, E. and Gesoğlu, M. (2008) 'A study on durability properties of high-performance concretes incorporating high replacement levels of slag', Materials and Structures, 41(3), p. 15.

Haha, M. Ben et al. (2011) 'Influence of activator type on hydration kinetics, hydrate assemblage and microstructural development of alkali activated blast-furnace slags', Cement and Concrete Research, 41(3), pp. 301-310.

Haha, M. Ben et al. (2011) 'Influence of slag chemistry on the hydration of alkali-activated blastfurnace slag - Part I: Effect of MgO', Cement and Concrete Research, 41(9), pp. 955-963.

Haha, M. Ben et al. (2012) 'Influence of slag chemistry on the hydration of alkali-activated blastfurnace slag - Part II: Effect of Al2O3', Cement and Concrete Research, 42(1), pp. 74-83.

Hogan, F. J. and Meusel, J. W. (1981) 'Evaluation for durability and strength development of a ground granulated blast furnace slag.', Cement Concrete Aggregate, 3(1), pp. 40-52.

Hossain, K. M. (2006) 'Performance of volcanic ash and pumice-based blended cements in sulphate and sulphate - chloride environments', Advances in Cement Research, 18, pp. 71-82.

Jeong, Y. et al. (2016) 'Influence of four additional activators on hydrated-lime $[\mathrm{Ca}(\mathrm{OH}) 2]$ activated ground granulated blast-furnace slag', Cement and Concrete Composites, 65, pp. 1-10.

Luke, K. and Glasser, F. P. (1988) 'Internal chemical evolution of the constitution of blended cements', Cement and Concrete Research, 18(4), pp. 495-502.

Lumley, J. S. et al. (1996) 'Degrees of reaction of the slag in some blends with Portland cements', Cement and Concrete Research, 26(1), pp. 139-151.

Luo, R. et al. (2003) 'Study of chloride binding and diffusion in GGBS concrete', Cement and Concrete Research, 33(1), pp. 1-7.

Ma, W. et al. (1994) 'Calorimetric study of cement blends containing fly ash, silica fume, and slag at elevated temperatures', Cement, Concrete and Aggregates, 16(2), pp. 93-99.

Mantel, D. G. (1994) 'Investigation into the hydraulic activity of five granulated blast furnace slags with eight different portland cements.', ACI Materials Journal, 91(5), pp. 471-477. 
Mehta, P. K. (1989) 'Pozzolanic and cementitious by-products in concrete--another look', ACI Special Publication, 114.

Miller, S. A. (2018) 'Supplementary cementitious materials to mitigate greenhouse gas emissions from concrete: can there be too much of a good thing?' Journal of Cleaner Production, 178, pp. 587598.

Moranville-Regourd, M. (2003) 'Cements Made from Blastfurnace Slag', in Lea's Chemistry of Cement and Concrete, pp. 637-678.

Ogirigbo, O. R. (2016) Influence of slag composition and temperature on the hydration and performance of slag blends in chloride environments, Civil Engineering. University of Leeds.

Ogirigbo, O. R. and Black, L. (2016) 'Influence of slag composition and temperature on the hydration and microstructure of slag blended cements', Construction and Building Materials, 126.

Ogirigbo, O. R. and Black, L. (2018) 'The effect of slag composition and curing duration on the chloride ingress resistance of slag-blended cements', Advances in Cement Research.

Ohimain, E. I. (2013) 'Scrap iron and steel recycling in Nigeria', Greener Journal of Environmental Management and Public Safety, 2(1), pp. 1-9.

Olonade, K. A., Kadiri, M. B. and Aderemi, P. O. (2015) 'Performance of steel slag as fine aggregate in structural concrete', Nigerian Journal of Technology (NIJOTECH), 34(3), pp. 452-458.

Olsson, N. et al. (2013) 'Non-saturated ion diffusion in concrete - A new approach to evaluate conductivity measurements', Cement and Concrete Composites, 40, pp. 40-47.

Oner, A. and Akyuz, S. (2007) 'An experimental study on optimum usage of GGBS for the compressive strength of concrete', Cement and Concrete Composites, 29, pp. 505-514.

Oss, V. H. (2002) Slag - Iron and Steel.

Oss, V. H. (2016) Iron and Steel Slag, U.S. Geological Survey, Mineral Commodity Summaries.

Pal, S. C., Mukherjee, A. and Pathak, S. R. (2003) 'Investigation of hydraulic activity of ground granulated blast furnace slag in concrete', Cement and Concrete Research, 33(9), pp. 1481-1486.

Ramezanianpour, A. A. and Malhotra, V. M. (1995) 'Effect of curing on the compressive strength, resistance to chloride-ion penetration and porosity of concretes incorporating slag, fly ash or silica fume', Cement and Concrete Composites, 17(2), pp. 125-133.

Regourd, M. (1986) 'Slags and slag cements', Cement replacement materials. Department of Mechanical Engineering, University of Sheffield, pp. 73-99.

Richardson, I. G., Wilding, C. R. and Dickson, M. J. (1989) 'The hydration of blastfurnace slag cements', Advances in Cement Research, 2(8), pp. 147-157.

Satarin, V. I. (1974) 'Slag portland cement', in The proceedings of the sixth internatinal congress of Chem. Cem.(VI ICCC), Moscow, pp. 1-51.

Scrivener, K. L. and Nonat, A. (2011) 'Hydration of cementitious materials, present and future', Cement and Concrete Research, 41(7), pp. 651-665.

Sengul, O. and Tasdemir, M. (2009) 'Compressive Strength and Rapid Chloride Permeability of Concretes with Ground Fly Ash and Slag', Journal of Materials in Civil Engineering, 21(9), pp. 494501. 
Shi, X. et al. (2011) 'Strength and corrosion properties of Portland cement mortar and concrete with mineral admixtures', Construction and Building Materials, 25(8), pp. 3245-3256.

Shi, X. et al. (2012) 'Durability of steel reinforced concrete in chloride environments: An overview', Construction and Building Materials, 30, pp. 125-138.

Siddique, R. and Bennacer, R. (2012) 'Use of iron and steel industry by-product (GGBS) in cement paste and mortar', Resources, Conservation and Recycling, 69(0), pp. 29-34.

Smolczyk, H. G. (1980) 'Slag structure and identification of slags', in 7th International Congress on the Chemistry of Cement. Paris, pp. 3-17.

Smolczyk, M. G. (1979) 'Effect of the chemistry of the slag on the strengths of blast furnace slags', Zement-Kalk-Gips. Wiesbaden, pp. 294-296.

Swamy, R. N. (1998) 'Design for durability and strength through the use of fly ash and slag in concrete', in CANMET/ACI International Workshop on Supplementary Cementing Materials, Superplasticizers and Other Chemical Admixtures in Concrete. Toronto, Canada: American Concrete Institute, pp. 1-72.

Thomas, M. D. A. et al. (2012) 'The effect of supplementary cementitious materials on chloride binding in hardened cement paste', Cement and Concrete Research, 42(1), pp. 1-7.

Ukpata, J. O., Basheer, P. A. M. and Black, L. (2018) 'Effects of Temperature and Curing Duration on the Stability of Slag Cements in Combined Chloride-Sulphate Environments', in Basheer, P. A. M. (ed.) 6th International Conference on Durability of Concrete Structures. Leeds: Dunbeath: Whittles, pp. 105-110.

Wan, H., Shui, Z. and Lin, Z. (2004) 'Analysis of geometric characteristics of GGBS particles and their influences on cement properties', Cement and Concrete Research, 34(1), pp. 133-137.

Wang, P. Z. et al. (2004) 'Influence of $\mathrm{Al} 2 \mathrm{O} 3$ content on hydraulic reactivity of granulated blastfurnace slag, and the interaction between $\mathrm{Al} 2 \mathrm{O} 3$ and $\mathrm{CaO}^{\prime}$, Advances in Cement Research, 16(1), pp. $1-7$.

Whittaker, M. et al. (2014) 'The role of the alumina content of slag, plus the presence of additional sulfate on the hydration and microstructure of Portland cement-slag blends', Cement and Concrete Research, 66(0), pp. 91-101.

Yeau, K. Y. and Kim, E. K. (2005) 'An experimental study on corrosion resistance of concrete with ground granulate blast-furnace slag', Cement and Concrete Research, 35(7), pp. 1391-1399. 